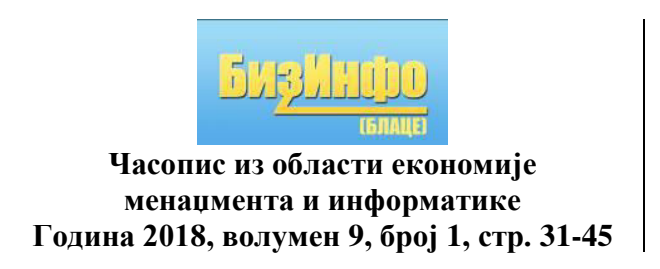

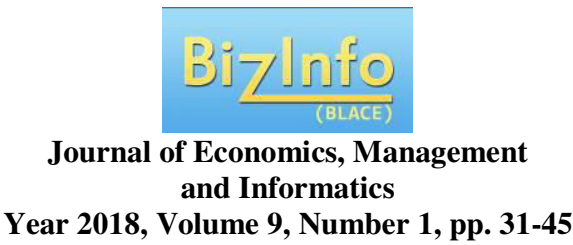

Стручни рад/ Professional paper

УДК/UDC: 005.6

658.562:621

\title{
THE MANAGEMENT SYSTEM INTEGRATION ON THE PRODUCTION PROCESS LEVEL
}

\section{ИНТЕГРАЦИЈА СИСТЕМА МЕНАЏМЕНТА НА НИВОУ ПРОИЗВОДНОГ ПРОЦЕСА}

\author{
Violeta Đorđević, Ljiljana Pecić ${ }^{1}$ \\ Bachelor School for Technical Engineering, Trstenik
}

\begin{abstract}
Market is today exposed to continuous changes and innovations in the field of product technology and timely the organization's reactions to those changes are necessary for securing the constant presence and survival on the market y. Only organizations that respond quickly to modern tendencies on the market and adapt them are competitive and competitive. The management system is a system for establishing the organization's policy and goals and achieving these goals. Many organizations that want to meet the quality requirements, environmental protection and the safety and security of people face the problem: how to do that and how to integrate different management systems. The integration of multiple systems into one is much more efficient and economical than the development and implementation of separate systems. This paper presents the short theoretical integration of three management systems: the quality of ISO 9000, the environmental protection of ISO 14000 and the protection of health and safety at work OHSAS 18000, and the practical integration of these three management systems at the level of the production process, observing the specific part from the production: Sito 40-504.412, which is an integral part of the product Hand pump 40-506.900.K1, PPT-Hydraulics.
\end{abstract}

Key words: managemet system integration, ISO 9000, ISO 14000, OHSAS 18000

\footnotetext{
${ }^{1}$ ljiljana.pecic@vtmsts.edu.rs
} 
Сажетак: Тржиште је данас изложено континуалним променама и иновачијама у области технологије производа, а благовремене реакиије организаиије на те промене су неопходне за осигурање константног присуства и опстанка на тржишту. Само организачије које брзо реагују на савремене тенденције на тржишту и прилагођавају се променама, остају конкурентне. Систем менаимента је систем утврђивања политике и ициева организачије и остваривања ових ииљева. Многе организаиије, које желе испунити захтеве по питању квалитета, заштите животне средине и сигурност $и$ безбедности људи, суочавају се са проблемом: како то учинити и како интегрисати различите системе менацмента. Интеграција више система у један је много ефикаснија и економичнија од развоја и имплементачије одвојених система. Овај рад представља кратку теоријску интеграцију три система менаимента: менаимент квалитетом ИСО 9000, менаимент заштитом животне средине ISO 14000 и менаимент заштитом здравља и безбедности на раду OHSAS 18000, те практичном интеграцијом ова три система управљања на нивоу производног проиес, а посматрајући специфичан део производње: Сито 40-504.412, који је саставни део производа Ручна пумпа 40-506.900.K1, ППТ-Хидраулика.

Кључне речи: интегрисани систем менаимента, ISO 9000, ISO 14000, OHSAS 18000

\section{INTRODUCTION}

Each organization needs appropriate leadership activities, in order to work according to established plans. These activities represents appropriate management system that sets goals and they ensure the achievement of these goals. One by one and separate introduction of the management system leads to their mutual independent functioning and provides different approaches and different solutions to certain problems that need to be solved. Therefore, it is necessary to use the similarities of different management systems by observing their requirements, goals, and what can be gained by integrating them into a unified integrated management system.

Although they have different bases, these systems have many similarities when we analyze their structure and organization, the process of implementation and achieving the required objectives, because they are all management systems. In all management systems, common elements can be found that can be managed in an integrated way.

This paper presents the theoretical integration of three management systems: the quality - ISO 9000, the environmental protection - ISO 14000 and the health protection and safety at work - OHSAS 18000, and the practical 
integration of these three management systems at the level of the production process, observing the specific part from the production: Sito (Sift) 40504.412 , which is an integral part of the product Hand pump 40-506.900.K1, PPT-Hydraulics.

\section{MANAGEMENT SYSTEMS}

The management system is a system for establishing policies and goals and for achieving these goals (ISO 9000: 2008). The management system is an "operational tool" for achieving the goals of an organization and it includes: organizational structure, policies, planned activities, responsibilities, business practices, procedures, processes, resources. These systems can provide the appropriate management and compliance in carrying out everyday activities, business and production processes. Management system standards are used in organizations to manage various aspects that relate to different organization activities. These standards are applyed on international level.

Management systems are implemented to enable managing of: production and quality, health and safety at work, environmental protection, security of information resources, risks, finances, etc., at the management level. They define a way to manage business functions and processes and they stretch across the entire organization. International standards provide models for the development and implementation of the system. Organization's business systems can be based on known international standards (ISO 9001, ISO 14001, ISO / IEC 27001, ISO 31001, OHSAS 18001, ...).

Depending on the type of product or service, the organizational needs and / or obligations for management system applications are set out in the following (Heleta, 2010):

- the requirements and needs of the community (the environment in which the organization operates): organizations do not operate isolated in one environment and they need to adapt to environmental demands (especialy to legal regulations;

- the requirements of the world market: having in mind that the European Union market is one of the largest markets in the world, and that it mostly requires business in accordance with the requirements of the management system, the necessity of business and the implementation of individual management systems;

- contractual obligations towards the user - fulfillment of the user's requirements: individual firms require their suppliers to apply some of the management system

- needs of the organization - owner, shareholder: the management system is not accepted because what is required by others, but because it is considered to be the basis of the organization's management system for 
the purpose of business success, and thus its survival in more and more demanding market.

The requirements of each management system include (to a greater or lesser extent) the following (Erdeljan, 2013):

- management: the responsibility of the management and their active action in achieving the set of goals. Through leadership and action, top management can create an environment in with staff fully involved and in which the quality management system can effectively function,

- Customer orientation: the organization works and exists for users of its products and all activities are directed towards meeting their demands, wishes and needs,

- Partner relationships with suppliers,Education and professional training of employees and

- Process approach: identifying processes and criteria and methods for measuring and improving performance internal checks.

\subsection{QUALITY MANAGEMENT SYSTEM ISO 9000}

Quality system standards were firstly created to regulate the quality of suppliers for the US military, and later accepted by NATO. These standards imposed quality management practices to a large number of suppliers, which should have been reliable, compatible and delivered on time, ie they garenteed the quality assurance. Under the qualiity assurance it is assumed activity quality assesment which is conducted by the side of independent evaluators, in order to provide necessary worker's and management selfconfidence (Juran and Gryna, 1974).

ISO 9000 was first published in the early 80's of the last century with the aim of establishing quality management and quality assurance standards. In the United Kingdom, the BS 5750 Standards were developed for commercial production organizations and were very similar to those military standards. They were accepted by the International Organization for Standardization (ISO) in 1987, and standard revisions were carried out in 1994, 2000 and 2008 (ISO 9001), in order to ensure the confidence in the output quality of a particular product, so before it comes in the hands of users, that is, consumers (Filipović and Đurić, 2009).

Canada (1978) and Great Britain (1979) were the first countries that provided their own National Quality Assurance Systems (Živković, 2012). 
The series of standards for quality management systems ISO 9000: 2008 includes the following three standards:

- ISO 9000: Quality management systems - Basics and vocabulary; contains the vocabulary and concept on which this series of standards is based and a description of the eight basic principles of quality management;

- ISO 9001: Quality management systems - Requirements; contains requirements in relation to which the organization will be audited and certified;

- ISO 9004: Quality Management Systems - Performance Improvement Guidelines; it should serve organizations as aid in continuous improvements.

The structure of the ISO 9000: 2008 series is based on a process-based process and they require the users to understand the QMS as a series of processes. This process-based structure is in line with the Plan Do Check Act (PDCA) cycle that is also included in the ISO 14000 series and can be applied to all processes.

The ISO 9000: 2008 model is based on eight basic quality management principles, which represent a comprehensive and fundamental rule or commitment to lead and manage the organization, with the aim of continuously improving performance over the long term, focusing on customer needs and all other stakeholders. The model shows that users have an important role in defining the input and output requirements. This standard focuses on the effectiveness of the quality management system when it comes to user requirements. It is also possible to integrate it with other standards, that is, with the Environmental Management System and the Occupational Health and Safety Management System. An important advantage of this standard is the clarity and precision of the process that is achieved through the description of all sectors in the organization.

Compliance with the standard is assessed by certification organizations, and not every customer is required to verify the reliability of the supplier. The certificate is a confirmation that the organization effectively manages its working processes.

The certificate does not guarantee the achievement of the required level of product quality; it also does not set requirements that are not important for the buyer (employee satisfaction, financial management, etc.), so the implementation of the ISO 9001 standard is only the first step in the process of continuous improvement. 
Figure 1. Process-based quality management model

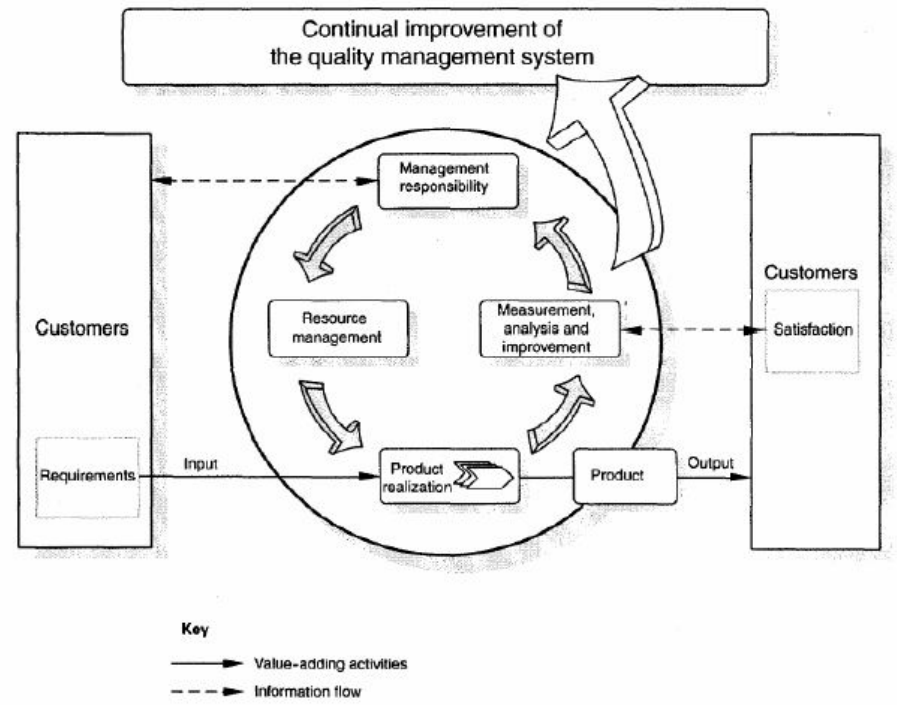

Source: Đapić, M., 2003. Integracija menadžment sistema na nivou proizvodnih procesa, Beograd: MMA.

The main part of the standard relates to requirementsthat are relating to the requirements of the quality management system, management responsibilities, resource management, product realization, measurement, analysis and improvement. Infrastructure, documentation, implementation, maintenance and continuous improvements are also important for each of these requirements.

\subsection{ENVIRONMENTAL PROTECTION MANAGEMENT SYSTEM ISO 14000}

Establishing a quality management system according to the ISO 9001 standard, the organization puts its processes under control, in order to achieve specified requirements for the product. Doing this, the organization does not control certain exits from the process, such as: various types of emissions into the atmosphere, wastewater, solid waste, resource consumption, and the like, which is the basic reason for environmental standardization, ie, appearance of the ISO 14000 series.

According to its purpose, the standards of the ISO 14000 series can be divided into normative (which define the requirements that must be met in order for the organization to obtain a certificate from an authorized organization) and information (that provide valuable information and instructions for the implementation of the necessary activities) in the following areas: terms and definitions in the field of environmental 
protection, implementation of audits of the environmental management system, environmental management system evaluation, environmental signs and declarations applications and life cycle assessments.

The ISO 14000 series enables organizations to control the impact of their environmental activities and products in accordance with prescribed laws. Increasing state regulations in this area leads to products that do not damage the environment. ISO 9001 and ISO 14001 are the most famous and most used ISO standards in the complete history of ISO organization. They have been implemented in more than a million organizations in 175 countries around the world.

This international standard establishes requirements for an environmental management system that should enable the organization to develop and implement policies and targets, taking into account legal requirements, as well as information on significant environmental aspects (ISO 14001: 2004). The issuance of the ISO 14001: 2004 standard was obtained by revising the previous edition of 1996, taking into account the requirements of the ISO 9001: 2000 standard in order to achieve the compatibility of these two standards.

\subsection{MANAGEMENT SYSTEM FOR HEALTH AND SAFETY OHSAS 18000}

The health and safety management system includes a set of coordinated strategies, activities and measures that are undertaken with the aim of: determining the risk of injuries at work, health disorders and occupational diseases, documentation of technical, technological and organizational protection measures and monitoring and controlling the negative impacts on the work environment.

Security management requires systemic and planned care regarding all activities and events in the work process which can in any way endanger the health and lives of people, and it is expressed through: health and safety policy, defining the objectives of health and safety at all relevant levels and all functions of the business system, identification and risk assessment and planning of protection measures, documented work safety system, Accident Report, Incident and Non-Compliance Reports, Records about conducted trainings and education about health and safety issues, a detailed inspection description and audit of health and safety and taking measures of continuous improvement.

Danger is all that can cause potential damage. Hazards can affect people, property, production processes, and can cause injuries at work and illness, 
loss of production, damage to machines and the like. The risk at work refers to the possibility of injuries or illnesses as a result of exposure to hazards. The main objective of risk assessment at work is to protect the safety and health of employees. Risk assessment helps in minimizing the possibility of employees or environment endanger during the work process performance (Vujović, 2009).

This series of standards was created due to the need for safety management in the work environment. Standard 18001 is similar in structure to ISO 14001 and is designed to integrate with ISO 9001 and ISO 14001. Since this standard is based on a process approach, the Deming Circuit (PDCA) is used to manage continuous improvement. The objective of the standard is to reduce the risk for employees on a minimum, and to provide a management tool that will enable continuous improvements in health and safety at work.

OHSAS 18001: 2007 is an industry standard for the implementation and certification of safety and health management systems, which has been adopted by a number of large corporations and is not an international standard and is not obligatory (OHSAS 18001:2007). The name OHSAS is an abbreviation that derives from the English title "Occupational Health and Safety Assesment Series Specifications". It was officially published in April 1999.

This standard is based on the British standard BS 8800 ("Guide to Occupational Health and Safety Management Systems", ie, "Guidelines for the management of health and safety systems of personnel") from 1996. Additional specifications and documentation have been provided by 15 international institutions and major corporations directly dealing with security and health issues (British Standards Institution, SGS, Lloyd, etc.). There are no accreditation schemes offered by national accreditation bodies, which are based on OHSAS 18001. Certification bodies can only issue non-accredited certificates for OHSAS 18001, e.g. Conformity Certificate.

\section{PROCEDURE FOR PRODUCTS PRODUCTION}

In ISO 9001: 2008 standard, point 4 refers to the quality management system. Within this framework are the requirements related to the documentation (4.2), and it consist of: general provisions, rules of procedure, document management and records management.

Documentation of the quality management system must include:

- Documented statements on quality policy and quality objectives,

- Quality Assurance Mannual, 
- Documented procedures and records required by this international standard,

- Documents, including records, which the organization has identified as necessary to ensure effective planning and execution of their processes, as well as management of those processes.

The specific product from the production "PPT - Hydraulics AD in restructuring", which explained the integration of the three standards, is Hand pump 40-506.900.K1 and its component Sito 40-504.412 (Dokumentacija proizvoda Ručna pumpa 40-506.900.K1).

There are procedures for carrying out every activity within the production process, from the process of product development to further. As a production procedure, a technological process is used (along with a flow chart), operating and regimenting sheets for making said product, which are attached. For each component, subassembly and assembly, there are documented procedures for its production.

As part of the product development process, serial production is at the very end of the product development process, and before that there is a prototype manufacturing (testing, review, validation) and the production of a "zero" series - pre-production.

For Sito 40-504.412 production procedure consists of:

- Material and parts requirements,

- locksmith works (010)

- locksmith works (020)

- electrical installation (030)

Note: Material and parts requirements - material is exterminated in total $1 \mathrm{~m}$ for 1000 pieces; Locksmithing (010) - reaming of rectangular shaped screen on measures 23mm x 30mm; Locksmith's works (020) - bending of sieves and overlapping to measure $\phi 5.8$ and perform a sieve screening on cota of $2 \mathrm{~mm}$ on the one side; Electrical installation (030) - brazing of the sieve 
Figure 2. Operational list

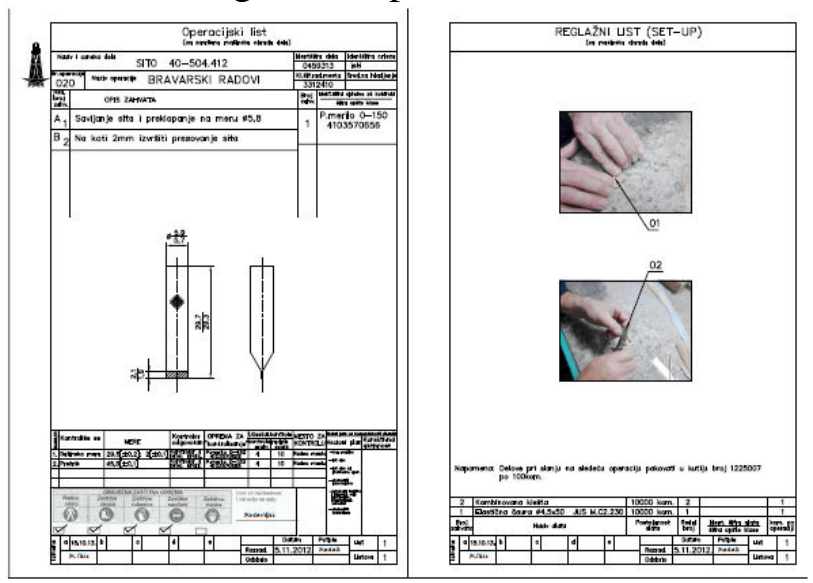

For each operation, there is an accompanying drawing (sketch) with all angles for prescribed processing, processing tools, measuring and control tools, control mode, packaging method, tool pictures and processing modes and action plans for non-conformity of the situation (machine failure, bad part).

\section{STANDARDS INTEGRATION}

An integrated management system is a management system that integrates all the systems and processes of an organization into a common system that gives common demands and goals. Management systems were gradually emerging, and so did their application in practice. Every organization that wants an integrated management system has to solve two issues: how to integrate multiple individual standards into one integrated system and how to get it all practically introduced into the organization's work. First, it is necessary to establish the interrelationships between integrated management systems that make the basis of that integration.

Establishing a unique integrated management system can be done in the next few steps (Erdeljan, 2013): establishing a request, selection of the strategy for the project realization, defining the structure of an integrated management system, developing documentation for adopted management systems and verification of compliance with the requirements of integrated management standards.

In the first step, the organization determines which standards it needs to integrate the management system (in this case the combination of ISO 9001, ISO 14001 and OHSAS 1800). Subsequently, the requirements of three standard management are presenting through a single integrated management system. In the third step, the names and designations of the ISO 9001 
standards are adopteding and the adopted integrated management system is documenting. The next step involves a period of practical application of a documented integrated system and training for all users in order to familiarize themselves with documentation and requirements, each within their scope of activities. In the fifth step an internal audit is conducted and, if everything is satisfactory, verification of compliance with the requirements of integrated management standards is carried out. In the end, proof of the abovementioned concordance is obtained.

Table 1. Basic elements of the model for the integration of the management system

\begin{tabular}{|c|c|}
\hline Policy & \multirow{2}{*}{ (Plan) } \\
\hline Planning & (Do) \\
\hline Implementation and operation & (Check) \\
\hline Performances Evaluation & (Act) \\
\hline Improvement &
\end{tabular}

The main framework elements for the integration of the management system within the organization can be grouped in the way shown in the following table. Each management system has its own specific requirements, but these six elements are present in each one and can be used as the basis for integration.

When considering these three standards - ISO 9001, ISO 14001 and OHSAS 18001, some of the common features of these systems are:

- Each of them focuses on one of the dimensions of business: quality, environmental protection, safety and protection at work,

- Based on the PDCA concept,

- They are based on a process approach, which involves defining business process processes, criteria and methods for their measurement, process monitoring and continuous measurement of process performance and their improvement

- Commitment of the management and their full involvement in the achievement of the set of goals,

- Each of them must be documented through policies, goals, rules of procedure, procedures and work instructions,

- Each of them strives to achieve the set of goals and continuous improvement, with employees involvement,

- Each of them has the same system of requirements that are reflecting through the management of documentation, records, internal checks, management, corrective and preventive measures, and review by the management side, 
- They are based on a system approach that involves identifying, understanding and managing a system of interconnected processes for given goal of improving the organizational effectiveness and efficiency.

The common requirements of the management system can practically be covered within a common system. In this way, the repetitions that come with the combination of two or more systems are omitted, and this gives greater system efficiency and effectiveness.

For the specified product Hand pump 40-506.900.K1 and its component Sita 40-504.412. the integration of these three standards in practice is presented in the following way. "PPT-Hydraulics" has already completed the integration of two standards ISO 9001 and OHSAS 18000 (with ISO / TS 16949: 2009 which is not the subject of this work), as can be seen on the operating leaflets, where the part with mandatory protective equipment (work clothing, protective shoes, protective gloves, protective goggles and protective mask) and marked items that are necessary for the given operation during the product preparation, prescribed by the person for safety and health at work.

Similarly, the integration of the ISO 14001 standards can be regulated. "PPTHydraulics", as an organization dealing with the machine industry, has nonhazardous waste and hazardous waste that can endanger the environment.

Figure 3. Mandatory protection equipment (original slide)

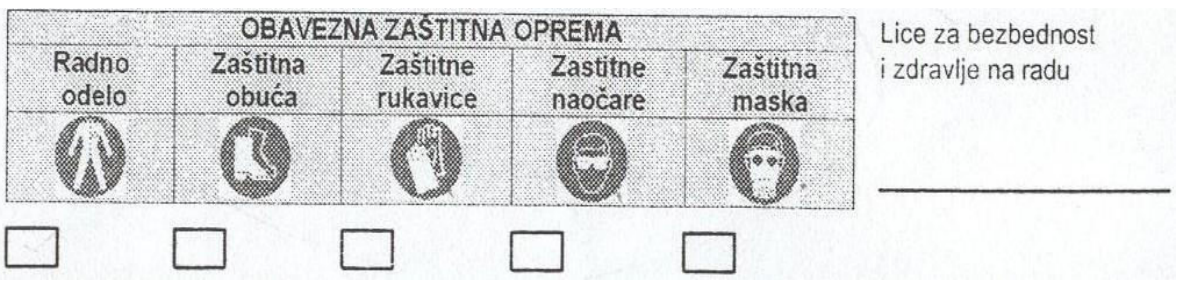

Wastes are material residues after processing (chips - sponge), most often steel and, in smaller quantities, brass, aluminum, tin. Each of these materials must be disposed of in containers designated for that purpose (especially for different types of materials) after completion of the processing, and then transferred to the boxes that exist in the factory. Later, these waste is taken over by authorized organizations and recycled.

Hazardous waste are various oils and emulsions used in the production process. They are also disposed of in anticipated containers and later they are taken over by the authorized organizations and departments, but in this case, three days before the transport, it is necessary to notify the Environmental Protection Agency, as hazardous waste is transported. 
Non-hazardous waste also contains hazardous waste. It is an oil and emulsions that are retained on the remains of the material after processing, so it is necessary before transportation (while the waste is in the boxes) to do the boiling. The non-dangerous waste material is placed at a certain height, so that hazardous waste is discharged into the space for which it is made, and then transported both by the already explained method.

In the concrete case, for the part Sito 40-504.412 the starting material (preparation) is a wire made of steel, no oil and emulsions are used, so the waste material is non-hazardous waste and does not endanger the environment. In the operating list, a section similar to the previous one for safety and safety at work could be introduced, where the obligatory method of disposal of waste would be envisaged and indicated, for example by styling, as in the previous case, where waste is deposited in the specific case. For easier access to workers, containers can be marked with different colors and determine which type of material is deposited in which container, e.g. steel waste in gray container, brass in blue, aluminum in green, tin in yellow, oil and emulsion in red etc.

In this case, for the part Sito 40-504.412, the waste is made of steel material and it would be disposed of in a steel waste container (eg in a gray container), and this would be indicated on the operating list by entering in the operating sheet a form for the mandatory disposal of waste in containers (environmental protection) and in which a gray container was styled. Figure 4 gives an overview of the form for environmental protection.

Figure 4 . Mandatory environment protection form

\begin{tabular}{|c|c|c|c|c|}
\hline \multicolumn{5}{|c|}{ MANDATORY WASTE DISPOSAL IN } \\
CONTAINERS \\
\hline gray & blue & green & yellow & red \\
\hline & & & & \\
\hline
\end{tabular}

\section{CONCLUSION}

Many organizations, that want to meet the requirements for quality, environmental protection and the safety and security of people, face the problem: how and in which manner to integrate different management systems. The integration of multiple systems into one is much more efficient and economical than the development and implementation of each separate systems. Each organization already has some form of an integrated management system because there is an obligation to apply legal regulations 
defined by the state, and it is necessary to respect and satisfy the requirements of all parties participating in the entire process, from customers to employees.

During the building an integrated management system, based on process management, all processes from the quality aspect, environmental protection and health and safety should be thoroughly analyzed and documented. In this example, the integrated management system is obtained when each element of the ISO 9001 standard is connected and complemented by elements of other standards - ISO 14001 and OHSAS 18001, that is, factors of human concern, environmental safety.

A good integrated management system, the one that brings results, meets all the requirements of all the standards that make up the given integration. Integration in practice is performed on certain processes and operations. The integrated management system this way formed, adapted to the organization activities, becomes a powerful tool of management for the development of business excellence.

\section{REFERENCES}

1. Evelina, E., Pia, G., David, H., von Würtemberg Liv, M., \& Waldo, R. F. 2010. Process improvement framework evaluation. In Management Science and Engineering (ICMSE), 2010 International Conference on (pp. 319-326). IEEE.

2. Erdeljan, Z., 2013. Zašto i kako integrisati menadžment sisteme. $U$ : QUALITY 2013. Neum, Bosnia and Herzegovina, 06-08 June 2013. Bosnia and Herzegovina: Univerzitet u Zenici.

3. Filipović, J., \& Đurić, M. 2009. Osnove kvaliteta. Beograd: Fakultet organizacionih nauka.

4. Vujović, R. 2009. Upravljanje rizicima i osiguranje. Beograd: Univerzitet Singidunum.

5. Juran, J., Gryna, F., 1974. Planiranje i analize kvaliteta. Beograd: Privredni pregled.

6. Mitrović, Ž. 1996. Osnove sistema kvaliteta. Beograd: Kultura.

7. Heleta, M. 2010. Projektovanje menadžment sistema životne i radne sredine. Univerzitet Singidunum.

8. Đapić, M., 2003. Integracija menadžment sistema na nivou proizvodnih procesa. Beograd: MMA.

9. Todorov, B. 1996. ISO 9000 required: Your worldwide passport to customer confidence. Productivity Press.

10. Živković, N. 2012. Integrisani sistemi menadžmenta. Beograd: Fakultet organizacionih nauka.

11. Institut za standardizaciju Srbije 2008. ISO 9001:2008 Sistemi menadžmenta kvalitetom-Zahtevi. Institut za standardizaciju Srbije. 
THE MANAGEMENT SYSTEM INTEGRATION ON THE PRODUCTION PROCESS LEVEL

12. ISO 14001:2004 Sistem upravljanja zaštitom životne sredine Zahtevi sa uputstvom za primenu

13. OHSAS 18001:2007 Sistem upravljanja zaštitom zdravlja i bezbednošću na radu - Zahtevi

14. Dokumentacija proizvoda Ručna pumpa 40-506.900.K1, PPTHidraulika.

Received: 22 March, 2018

Accepted: 4 May, 2018 
